\title{
XXXII. On steam-boats
}

\section{Robertson Buchanan Esq.}

To cite this article: Robertson Buchanan Esq. (1815) XXXII. On steam-boats, Philosophical Magazine Series 1, 45:203, 181-183, DOI: $10.1080 / 14786441508638412$

To link to this article: http://dx.doi.org/10.1080/14786441508638412

曲 Published online: 27 Jul 2009.

Submit your article to this journal 중

Q View related articles $₫$ 
when the dispute on this subject took place between Hooke, Huyghens, and others. Whether Richard Harris was, I know not.

$$
\text { I am, sir, }
$$

Your most obedient humble servant, Thomas REID.

XXXII. On Steam-Boats. By Rouertson Duchanan, Esq. of Glasgow.

To Mr. Tilloch.

Drar Sir, - A grefabity to your request. I now send you some account of the steani-boats on the Clyde.

I am, dear sir,

Your most obedient servant,

$$
\text { Glasgow, Jimuary 9, 1815. RoBertson BuCHANan. }
$$

So early as the year 1801 , a vessel propelled by steam was tried on the Forth and Clyde inland navigation, but was laid aside, among other reasons, on account of the injury it threatened the banks of the canal by the agitation of the water: and as far as I can learn, the same objection still subsists to the use of steam boats on artificial canals so narrow as those usual in Great Britain. That objection, however, I should think, does not apply to some of those of Holland and other countries on the continent.

The first attempt on any scale worthy of notice, to navigate by steam on the river Clyde, was in the year $1812 \%$. A passage boat of about 40 feet keel and $10 \frac{1}{2}$ feet beam, having a stcamengine of only three horses' power, hegan to ply on the river. Since that period the number of boats has gradually increased.

Besides three vessels' which have left the Clyde, there are six at present plying on the river, two of which carry goods as well as passengers. They have on the whole been gradually increased in tonnage as well as in the power of their engines; and still larger boats and more powerful engines are now constructing: among others, one of about 100 feet keel and 17 feet beam with an engine of 24 horses' power; and one of equal burthen, having an engine of 30 horses' power $t$. These boats are all neatiy fitted up, and some of them even elegantly decorated,

On board all the passage steam-boats are newspapers, pam-

* The first steam-boat in Amcrica was launched at New-York on the $3 \mathrm{~d}$ of October 1807 , and began to ply on the river between that city and Albany, a distance of about 120 miles.

+ For the value of a horse's power, see Buchanan's Essay on Mill-worl, Teeth of Wheels, p. 130. 
phlets, books, \&c. for the amusement of the passengers, and such refreshments as are desirable on so short a voyage, a distance of about 26 miles by water, and 24 by land.

The voyage beiwixt Glasgrow and Greenock, including stoppages at intermediate places, is commonly accomplished in from three to four hours, the vessels taking advantage of the tide as far as eircumstances will permit : but as they start at different hours from the same place, they are sometimes obliged to go part or nearly the whole of their vovage against the tide.

The voyage has been accomplished in $2 \frac{1}{4}$ hours; the tide being favourable, but against a morlerate breeze of contrary wind *

At first, owing to the novelty and apparent danger of the conveyance, the number of passengers was so very small that the only steam-boat then on the river could hardly clear her expenses: but the degree of success which attended that attempt soon commanded public confidence. The number of passengers which now go in those boats may seem incredible to those who have not witnessed it. Travelling by land has not only been nearly superseded, but the communication very greatly increased, owing to the cheapness and facility of the eonveyance. Many days, in fine weather, from 500 to 600 have gone from Glasgow to Port-Glasgow and Greenock, and returned in the same day. Orie of the boats alone has been known to carry 247 at one time. The increase of travelling in consequence of navigation by steam, may be estimated by the number that went in the common passage boats before the introduction of this agent : at that time, the highest estimate even for summer did not much exceed 50 up and 50 down, and those generally of the lower class of the people: The number that then went by coaches may be thus estimated: four coaches up and four down, which might average six passengers each.

In the summer, the pleasure of the voyage and the beauty of the scenery attract multitudes; and the bathing-places below Greenock have, in consequence of the easy passage, been crowded beyond former example.

"The scenery near Glasgow is sylvan and beantiful, but becomes bolder aud more picturesque as the river descends, until it terminate in the rugged mountains of the west Highlands.

Robertson Buchavan.

\section{Genteral Description.}

A variety of modes of propelling steam-boats by the power of steam-engines have been projected, and many of them tried: but

* The time which was allowed to the Mail coach to go between those towns was $3 \frac{1}{2}$ hours, but owing to extraordinary excrion some of the cuacies nuw run that distance in abqut $2 \frac{x}{2}$ hours, 
On the Embryo of the Seeds formod in the Root alone. 183

those on the Clyde have their machinery all construeted on on general plan; namely, that of paddle-wheels similar to undershot water-mill wheels on each side of the vessel, which are put in motion by the steam-engine.

Reference to Drawings of Steam-Boat.

Plate III. An elevation; a side view showing one of the paddle wheels.

IV. A plan, showing the extent of cabin floor.

A. The fore or second cabin.

BB. Space for the machinery.

C. The iron chimney, serving also as a mast.

D. The boiler.

EE. The steam-engine.

G. The crank.

H. The fly-wheel.

II. The paddle-wheels.

h. Ladies' cabin.

L. Steward's room.

M. Principal cabin.

NN. Stairs down to the cakins.

OO. Water closet.

PP \&c. Gangway.

QQQ. Seats at stern and on the deck.

R. The rulder.

S. Covering of paddle-wheels.

XXXIII. A Paper proning that the Embryos of the Seed's are formed in the Roat alone. By Mrs. AgNes lBbETsox.

$$
\text { To Mr. Tilloch. }
$$

7 Sharwood, Fcb. 24, 1815.

Sir,- I hat time is anw arrived, of whin I hat year promised to give notice, when the seeds are to be discovered mounting in the abburnum vessels from the root. It is a phenomenon so. easily seen, that I camot help caling on botanists in general to convince themselves of a fact of stich ronsequence to science, and establishing the folindation (if admitted) of a more perfect knowledge in the formation of plants than we yet possess. It requires no other preparation (to view it well) than merely cutting off a small piece of the outward rind of any trec, then cutting an extremely thin slice adjoining the several cuticles, which if it is the proper piece (that is the alburnum vessels) it will be so soft as to cut with the utmost ease. In this specimen, with the naked eve, if held up to the light, but certainly with a small magnifier, the seeds will be seen mounting the tree. I shall first give a $\mathrm{M} 4$ completo 